\title{
Mechanizmy regulacyjne fazy świetlnej fotosyntezy u roślin wyższych
}

\section{lic. Anna Węgrzyn, \\ dr Radosław Mazur ${ }^{\varpi}$}

Zakład Regulacji Metabolizmu, Instytut Biochemii, Wydział Biologii, Uniwersytet Warszawski

https://doi.org/10.18388/pb.2020_325

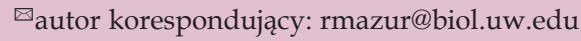
$\mathrm{pl}$

Słowa kluczowe: chloroplastowy łańcuch transportu elektronów, fotoinhibicja, fotosynteza, niefotochemiczne wygaszanie energii wzbudzenia, przejście stanów

Wykaz skrótów: CET - cykliczny transport elektronów; LET - liniowy transport elektronów NPQ - niefotochemiczne wygaszanie energii wzbudzenia; PSI - Fotosystem I; PSII - Fotosystem II

\section{STRESZCZENIE}

Gaza świetlna fotosyntezy jest kluczowym procesem energetycznym u roślin wyższych. - Jej celem jest konwersja energii świetlnej w energię chemiczną w postaci ATP i NADPH, które są następnie wykorzystywane do asymilacji $\mathrm{CO}_{2}$ oraz szeregu innych procesów metabolicznych. Utrzymanie optymalnej wydajności procesu fotosyntezy wymaga ścisłej regulacji organizacji błon tylakoidów i szybkiego reagowania na zmienne warunki środowiska. Głównym czynnikiem wpływającym na wydajność fotosyntezy jest światło, które w zbyt wysokim natężeniu prowadzi do spowolnienia procesu. Dlatego rośliny wykształciły szereg mechanizmów ochronnych regulujących reakcje świetlne fotosyntezy i działających na poziomie absorpcji energii świetlnej, transportu elektronów oraz dystrybucji i wykorzystania siły redukcyjnej. Należą do nich $\mathrm{m}$. in.: (i) niefotochemiczne wygaszanie energii regulujące ilość dostarczanej energii wzbudzenia; (ii) proces przejścia stanów redystrybuujący ją pomiędzy fotosystemami; (iii) redundantne szlaki transportu elektronów odpowiadające za utrzymanie równowagi redoks $w$ chloroplastach. Wszystkie te mechanizmy, w połączeniu $z$ systemami antyoksydacyjnymi, mają na celu utrzymanie funkcji aparatu fotosyntetycznego w niesprzyjających warunkach wzrostu.

\section{WPROWADZENIE}

Fotosynteza, podstawa funkcjonowania większości ekosystemów na Ziemi, jest biochemicznym procesem syntezy związków organicznych wykorzystującym światło słoneczne jako źródło energii. Podzielona jest na dwa etapy: fazę świetlną oraz niezależną od światła fazę ciemną. W fazie świetlnej następuje przekształcenie energii fotonów na energię chemiczną zgromadzoną w cząsteczkach ATP oraz siłę redukującą cząsteczek NADPH. W fazie ciemnej zachodzi proces wiązania i redukcji $\mathrm{CO}_{2}$, w trakcie którego następuje wykorzystanie energii powstałej $w$ fazie świetlnej. U roślin wyższych proces fotosyntezy ma miejsce w chloroplastach, a jej dwa etapy są rozdzielone przestrzennie: faza świetlna zachodzi w wewnętrznych błonach chloroplastowych, zwanych tylakoidami, gdzie znajdują się kompleksy białkowo-barwnikowe katalizujące reakcje fotochemiczne, natomiast faza ciemna przebiega w stromie chloroplastowej zawierającej enzymy cyklu Calvina-Bensona-Basshama [1].

\section{KOMPLEKSY FOTOSYNTETYCZNE BŁON TYLAKOIDÓW}

W błonach tylakoidów zlokalizowane są kompleksy barwnikowo-białkowe katalizujące reakcje fotochemiczne i oksydoredukcyjne w trakcie fazy świetlnej fotosyntezy. Są to fotosystem II (PSII) i fotosystem I (PSI) wraz z kompleksami antenowymi LHC (ang. light harvesting complex), odpowiedzialnymi za zbieranie i przekazywanie energii świetlnej, odpowiednio LHCII i LHCI. W fotosystemach zachodzą procesy absorpcji fotonów i wybicia elektronów, które są następnie przenoszone na kolejne akceptory szlaku transportu elektronów, w którym cytochrom $\mathrm{b}_{6} f\left(\mathrm{Cyt}_{6} f\right)$ występuje jako kompleks pośredniczący między PSII i PSI [2]. Z transportem elektronów w płaszczyźnie bocznej błony tylakoidowej sprzężony jest transport protonów w poprzek błony, w wyniku którego powstaje siła protonomotoryczna wykorzystywana do syntezy ATP przez kompleks chloroplastowej syntazy ATP [3].

\section{FOTOSYSTEM II I KOMPLEKSY ANTENOWE LHCII}

Rdzeń białkowy PSII składa się z czterech dużych podjednostek: D1 (PsbA), D2 (PsbD), CP43 (PsbC) i CP47 (PsbB). Heterodimer białek D1-D2 tworzy szkielet białkowy dla centrum reakcji P680 oraz pierwotnych i wtórnych akceptorów elektronów, natomiast podjednostki CP43 i CP47 stanowią wewnętrzne anteny przekazujące energię wzbudzenia do centrum reakcji. W skład części błonowej PSII wchodzą także białka PsbE i PsbF tworzące podjednostkę cytochromu $\mathrm{b}_{559}$ oraz białka PsbH-M, PsbTc, PsbTn PsbW, PsbX, PsbZ będące białkami o niskiej 
masie cząsteczkowej nie zawierającymi chlorofilu. Funkcją tych białek jest $\mathrm{m}$. in.: stabilizacja barwników związanych z PSII, stabilizacja i udział w dimeryzacji PSII oraz udział w wiązaniu anten LHCII z PSII. Od strony lumen (inaczej światła) tylakoidów znajdują się trzy zewnątrzbłonowe białka: PsbO, PsbP i PsbQ, które wraz z C-końcowym fragmentem D1 tworzą czaszę stabilizującą kompleks wydzielający tlen (ang. oxygen evolving complex, OEC). Centralną częścią OEC jest semikrystaliczny kompleks $\mathrm{Mn}_{3} \mathrm{CaO}_{4}$, połączony mostkiem tlenowym z czwartym atomem manganu i wiązany przez podjednostki D1 i CP43 [4-6].

Głównym kompleksem antenowym PSII jest LHCII, występujący $\mathrm{w}$ formie trimerów zbudowanych $\mathrm{z}$ homologicznych białek wiążących chlorofile $a$ i $b$ : Lhcb1, Lhcb2 i Lhcb3. Trimery LHCII występują w kilku konfiguracjach homo- i heterotrimerów, w zależności od swej lokalizacji i funkcji $[4,7,8]$. Oprócz trimerycznych LHCII z PSII są związane również mniejsze monomeryczne kompleksy antenowe: Lhcb4 (CP29), Lhcb5 (CP26) i Lhcb6 (CP24) [9,10].

Rdzeń PSII występuje w formie dimeru, który może wiązać od czterech do sześciu trimerów LHCII. Trimery w zależności od siły wiązania z rdzeniem PSII dzieli się na trzy typy S, M i L (odpowiednio silnie, umiarkowanie i słabo związane) $[8,11]$. Dimeryczny rdzeń PSII $\left(\mathrm{C}_{2}\right)$ wraz z antenami LHCII jest określany jako superkompleks PSII-LHCII. Podstawową jednostkę PSII-LHCII stanowi kompleks typu $\mathrm{C}_{2} \mathrm{~S}_{2}$, który zawiera dwa trimery LHCII typu $\mathrm{S}$ oraz po dwie anteny CP29 i CP26. Każdy z trimerów LHCII jest połączony z rdzeniem PSII poprzez CP29 i CP26. Superkompleks typu $\mathrm{C}_{2} \mathrm{~S}_{2} \mathrm{M}_{2}$ zawiera dwa dodatkowe trimery LHCII typu $\mathrm{M}$ oraz dwie anteny CP24. Trimery typu $\mathrm{M}$ są połączone z rdzeniem fotosystemu za pomoca anten CP29 i CP24 [10]. Superkompleksy zawierające trimery LHCII typu L nie są często spotykane. W zależności od liczby i rodzaju przyłączonych trimerów oraz monomerycznych białek antenowych superkompleksy PSII-LHCII wykazują inne właściwości fizyko-chemiczne, które determinują ich funkcję i zdolność do tworzenia struktur wyższego rzędu np. megakompleksów i mikrodomen [7].

\section{FOTOSYSTEM I I KOMPLEKSY ANTENOWE LHCI}

Rdzeń PSI tworzy heterodimer białek PsaA i PsaB, w którym zlokalizowane jest centrum reakcji P700 [5,12,13]. Rdzeń PSI wiąże chlorofile i $\beta$-karoten zaangażowane $\mathrm{w}$ zbieranie energii świetlnej oraz chlorofile, filochinony i centrum żelazowo-siarkowe [4Fe-4S], będące pierwotnymi i wtórnymi przenośnikami elektronów [5,14]. W skład rdzenia PSI wchodzą również: (i) białka PsaC, D, E, wiążące centra żelazowo-siarkowe [4Fe-4S] (PsaC) i tworzące miejsce wiązania ferredoksyny (PsaC-E), (ii) podjednostki PsaF, PsaN tworzące platformę dla dokowania plastocyjaniny oraz (iii) mniejsze podjednostki odpowiedzialne za stabilizację fotosystemu, wiązanie białek antenowych i interakcje z innymi kompleksami błon tylakoidów. Podobnie jak PSII, PSI posiada zewnętrzne kompleksy antenowe Lhca1-Lhca6. Białka Lhca1-Lhca4 tworzą półpierścień wokół części rdzeniowej fotosystemu formując superkompleks PSI-LHCI [12,15]. Za wiązanie białek LHCI z częścią rdzeniową PSI i stabilizację całego kompleksu są odpowiedzialne pod- jednostki PsaK i PsaG wspomagane przez PsaF (wiązanie dimeru anten Lhca1-Lhca4) i PsaN (wiązanie dimeru anten Lhca2-Lhca3) [16]. Białka Lhca5 i Lhca6 odpowiadają za interakcje PSI z kompleksem chloroplastowej dehydrogenazy $\mathrm{NDH}$ (ang. NADH dehydrogenase-like complex) [17]. W określonych warunkach świetlnych PSI może wykorzystywać trimery LHCII jako własne białka antenowe poprzez formowanie superkompleksu PSI-LHCI-LHCII [5, 12, 18]. Podjednostki PsaH, PsaI, PsaL, PsaO i PsaP tworzą miejsce wiązania LHCII. Samo przyłączenie anten LHCII do PSI-LHCI jest efektem aktywności procesu przejścia stanów (ang. state transition) omówionego w dalszej części artykułu [18].

\section{CYTOCHROM $b_{\sigma} f$}

Kompleks Cyt bf występuje jako dimer - każdy z monomerów składa się z czterech dużych podjednostek: cytochromu $f($ Pet $A)$, cytochromu $b_{6}($ Pet $B)$, białka żelazowo-siarkowego Rieskiego (PetC) i podjednostki IV (PetD), w których zlokalizowane są kofaktory biorace udział w reakcjach redoks, oraz kolejnych czterech mniejszych podjednostek odpowiedzialnych za stabilizację kompleksu $[19,20]$. Cyt $\mathrm{b}_{6} f$ jest zaangażowany m.in. w transport elektronów pomiędzy fotosystemami, tworzenie gradientu protonów w poprzek błony i aktywację procesu przejścia stanów [19,21].

\section{SYNTAZA ATP}

Chloroplastowa Syntaza ATP nazywana kompleksem CF1-CF0 (ang. Chloroplast Factor 1 - Chloroplast Factor 0) zbudowana jest $\mathrm{z}$ dwóch jednostek [22,23]. Jednostka CF0 jest stabilnym kanałem zakotwiczonym w błonie tylakoidowej, który składa się z czterech różnych białek (I-IV) i odpowiada za transport protonów w poprzek błony. Część CF1 - skierowana do stromy chloroplastu, jest zbudowana $\mathrm{z}$ pięciu podjednostek o stechiometrii $a_{3} \beta_{3} \gamma \delta \varepsilon$, z których naprzemiennie ułożone podjednostki a i $\beta$ tworzą pierścień. W podjednostkach $\beta$ na styku z podjednostkami a znajdują się trzy centra katalityczne, w których zachodzi synteza ATP z ADP i nieorganicznego ortofosforanu. $\mathrm{Z}$ pierścieniem połączone są podjednostki ү i \& tworzące centralny rdzeń (rotor) kompleksu, natomiast podjednostka $\delta$ bierze udział w stabilizacji całego kompleksu i zapobiega obrotowi części katalitycznej enzymu [24,25]. Przepływ protonów przez jednostkę CF0 generuje obrót rotora kompleksu syntazy ATP - oddziaływania mechaniczne rotora $\mathrm{z}$ pierścieniem katalitycznym powodują zmiany konformacyjne miejsc katalitycznych umożliwiając syntezę ATP. Pełny obrót pierścienia, w trakcie którego następuje przetransportowanie 14 protonów z lumen do stromy, umożliwia syntezę trzech cząsteczek ATP $[5,28]$.

\section{FOTOSYNTETYCZNY ŁAŃCUCH TRANSPORTU ELEKTRONÓW}

Faza świetlna fotosyntezy jest napędzana przez dwie fotochemiczne reakcje katalizowane przez PSII i PSI, które są połączone łańcuchem transportu elektronów [3]. Liniowy transport elektronów (LET) w błonach tylakoidów napędza syntezę NADPH i ATP, natomiast cykliczny transport elektronów (CET) wokół PSI prowadzi do syntezy jedynie ATP (Ryc. 1). Wydajność LET i CET jest precyzyjnie regulowana w celu zachowania odpowiedniego stosunku ATP/NADPH 


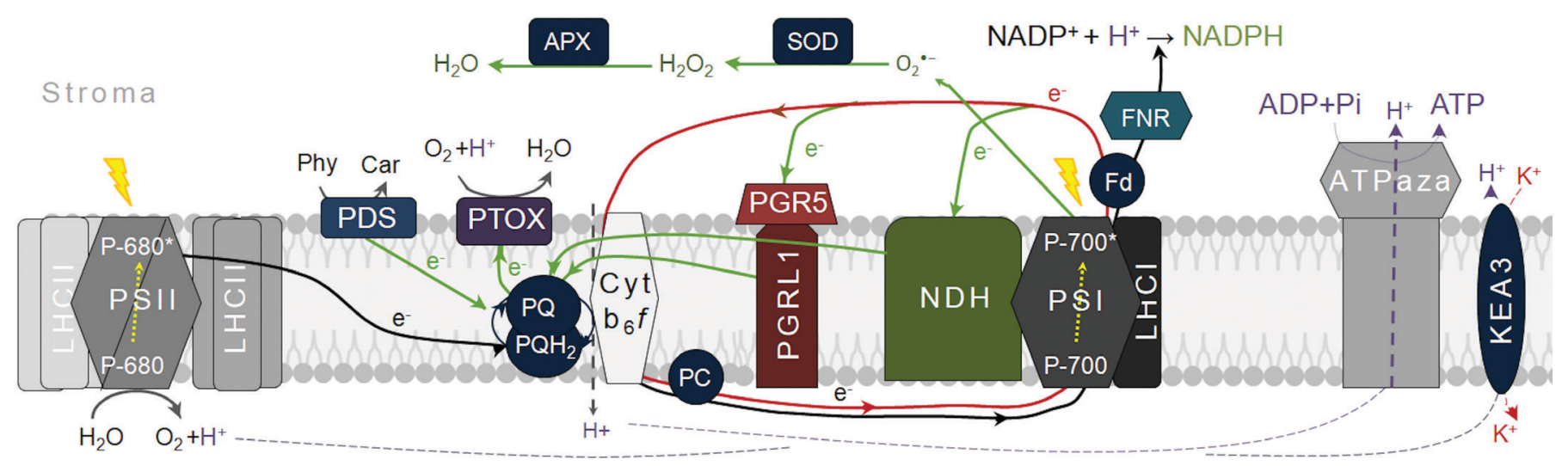

Lumen

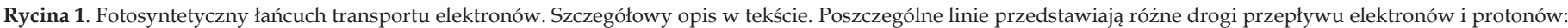

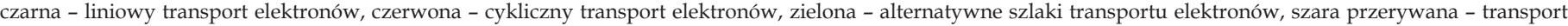

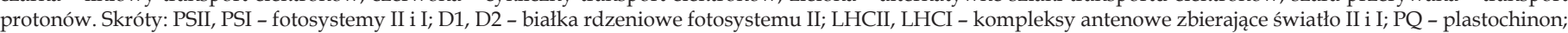

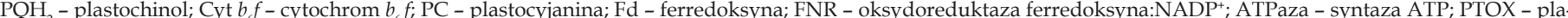

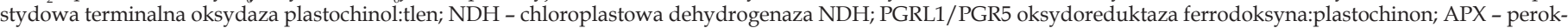
sydaza L-askorbinianowa; SOD - dysmutaza ponadtlenkowa; KEA3 - antyporter K+ 3; PDS - desaturaza fitoenu; Phy - fitoen; Car - karotenoidy.

niezbędnego do funkcjonowania fazy ciemnej fotosyntezy [26]. W przypadku zachwiania stosunku NADPH/NADP ${ }^{+}$ - prowadzącego do zaburzenia stanu redoks chloroplastów, następuje zwiększenie aktywności alternatywnych szlaków transportu elektronów, do których należą m.in.: alternatywne drogi zamknięcia CET, chlororespiracja i cykl woda-woda (Ryc. 1) [27].

\section{LINIOWY TRANSPORT ELEKTRONÓW}

Kompleksy antenowe PSII absorbują energię fotonu, która jest następnie przekazywana w postaci wzbudzenia elektronowego na parę chlorofili $a \mathrm{w}$ centrum reakcji P680, które staje się silnym reduktorem. P680 przekazuje wtedy elektron na feofitynę $a$ i dochodzi tym samym do separacji ładunków. Powstały kation P680+ może zostać zredukowany dzięki elektronom uwolnionym w wyniku utlenienia wody w kompleksie OEC zlokalizowanym po lumenalnej stronie błony tylakoidowej. Uwolnienie elektronów z wody jest związane ze zmianami stanu redoks OEC określanymi jako cykl S (S0-S4); utlenienie jednej cząsteczki wody wymaga absorbcji czterech fotonów przez centrum reakcji PSII, a sam mechanizm rozszczepienia jest związany ze zmianami stopnia utlenienia jonów manganu $[1,11,28]$. Zredukowana feofityna a przekazuje elektron na cząsteczkę plastochinonu (PQ), silnie związanego z kompleksem w miejscu $\mathrm{Q}_{\mathrm{A}^{\prime}}$ który przechodzi w formę semichinonową i przekazuje elektron na inną cząsteczkę PQ luźno związaną w miejscu $\mathrm{Q}_{\mathrm{B}}$. Po dwóch jednoelektronowych redukcjach i przyłączeniu dwóch protonów po stromalnej stronie błony, zredukowany plastochinon (plastochinol, $\mathrm{PQH}_{2}$ ) zostaje uwolniony $\mathrm{z}$ miejsca $\mathrm{Q}_{\mathrm{B}^{\prime}}$ a jego miejsce zajmuje inna cząsteczka $\mathrm{PQ}[29,30] . \mathrm{PQH}_{2}$ przemieszcza się $\mathrm{w}$ błonie tylakoidowej, transportując elektrony do kompleksu Cyt $b_{6} f$, pełniącego funkcję oksydoreduktazy plastochinol:plastocyjanina.

Niezależnie od PSII, wzbudzeniu ulega centrum reakcji PSI - P700, które przekazuje elektron na cząsteczkę Chl a (A0), będącą pierwotnym akceptorem elektronów. Następ- nie elektron trafia na cząsteczkę filochinonu $A_{1}$, która przekazuje go na centra żelazowo-siarkowe [4Fe-4S] (kolejno Fx, $\mathrm{F}_{\mathrm{B}}$ i $\mathrm{F}_{\mathrm{A}}$ ) i ostatecznie na ferredoksynę (Fd) [35]. Zredukowana Fd w obecności enzymu oksydoreduktazy ferredoksyna:NADP ${ }^{+}$(FNR) przekazuje elektrony na NADP ${ }^{+}$, w wyniku czego powstaje NADPH. Natomiast zredukowana przez Cyt $b$ f plastocyjanina (PC) zostaje donorem elektronów dla utlenionego centrum reakcji P700 ${ }^{+}[11,28,31]$.

\section{CYKL Q I CYKLICZNY TRANSPORT ELEKTRONÓW}

CET obejmuje reakcje fotochemiczne w PSI i aktywność kompleksu Cyt $b_{6} f$ z wyłączeniem PSII [32] i utrzymuje stronę akceptorową PSI w formie utlenionej, co chroni PSI przed uszkodzeniem [65]. Kompleks Cyt $b_{6} f$ sprzęga liniowy i cykliczny transport elektronów z transportem protonów ze stromy chloroplastów do lumen tylakoidów dzięki działaniu tzw. cyklu Q, w trakcie którego zachodzi utlenienie $\mathrm{PQH}_{2}$ na drodze dwóch niezależnych reakcji redoks. Cząsteczka $\mathrm{PQH}_{2}$ po wniknięciu do lipofilnej przestrzeni w kompleksie Cyt $b_{6} f$ oddaje dwa elektrony z jednoczesnym uwolnieniem protonów do lumen tylakoidów. Jeden z elektronów redukuje centrum żelazowo-siarkowe FeS Rieskiego, następnie elektron ten trafia na Cyt $f$, który z kolei przekazuje go na cząsteczkę PC, a w ostateczności na PSI [34]. Drugi z elektronów, uwolnionych z $\mathrm{PQH}_{2}$, przechodzi na hem Cyt $b_{6 n}$ o niskim potencjale, następnie na hem $\mathrm{b}_{6 \mathrm{w}} \mathrm{O}$ wysokim potencjale, gdzie następuje redukcja PQ umiejscowionego po stromalnej stronie kompleksu $\mathrm{b}_{6} f$. Po dwóch jednoelektronowych redukcjach i przyłączeniu $2 \mathrm{H}^{+}$ ze stromy chloroplastu $\mathrm{PQH}_{2}$ migruje do powierzchni lumenalnej błony, gdzie ponownie może oddać elektrony na centrum FeS Rieskiego. Efektem działania cyklu Q jest więc zintensyfikowanie transportu protonów do lumen tylakoidów [34,35]. W przypadku CET donorem dla kompleksu Cyt $b_{6} f$ jest Fd (bądź kompleks Fd-FNR), a bezpośrednim akceptorem sprzężony kompleks hemów Cyt $b_{6}$, redukujący następnie cząsteczkę PQ, która po dyfuzji do lumenalnej powierzchni błony wchodzi w reakcje cyklu Q [34]. 
ALTERNATYWNE DROGI ZAMKNIECIA

CYKLICZNEGO TRANSPORTU ELEKTRONÓW

Poza możliwością utlenienia Fd w kompleksie Cyt $b_{6} f_{1}$ istnieją alternatywne szlaki wykorzystujące dodatkowe enzymy obecne $\mathrm{w}$ błonach tylakoidów. Pierwsza $\mathrm{z}$ nich wykorzystuje białka PGR5 (ang. Protein Proton Gradient Regulation 5) i PGRL1 (ang. PGR5-like protein 1). Białko PGRL1 zostało zidentyfikowane jako oksydoreduktaza ferrodoksyna:plastochinon, natomiast białko PGR5 jest niezbędne dla aktywności PGRL1. W szlaku wykorzystującym PGR5/ PGRL1 elektrony z Fd są przekazywane na PQ, który po zredukowaniu wchodzi w reakcje cyklu Q [36]. Drugi szlak redukcji PQ prowadzi przez chloroplastowy kompleks NDH, który również wykazuje aktywność oksydoreduktazy ferrodoksyna:plastochinon [32]. Pierwotnie uważano, że źródłem elektronów dla kompleksu NDH jest NADPH (stąd też pierwotna potoczna nazwa enzymu - dehydrogenaza NADPH). Ścieżki transportu elektronów angażujące NDH i PGR5/PGRL1 są względem siebie komplementarne i mogą być aktywne w ciemności wpływając tym samym na stopień redukcji PQ w ciemności [37, 38]. Jest to istotne, ponieważ poziom redukcji puli PQ jest ważnym wskaźnikiem stanu redoks tylakoidów i wpływa na regulację ekspresji genów chloroplastowych oraz jądrowych $[34,35,39]$.

\section{CHLORORESPIRACJA}

Nadmierny poziom redukcji PQ może zostać usunięty na drodze procesu chlororespiracji, katalizowanego przez plastydową terminalną oksydazę plastochinol:tlen (PTOX), poprzez przeniesienie elektronów z $\mathrm{PQH}_{2}$ na $\mathrm{O}_{2}$ z wytworzeniem $\mathrm{H}_{2} \mathrm{O}$. Działanie PTOX jest analogiczne do mitochondrialnej alternatywnej oksydazy (AOX). PTOX reguluje równowagę między CET a LET $[63,65]$. Aktywność PTOX wzrasta wraz z aktywnością alternatywnych dróg zamknięcia CET, które zwiększają poziom redukcji PQ.

\section{CYKL WODA-WODA}

W cyklu woda-woda źródłem elektronów i produktem końcowym jest $\mathrm{H}_{2} \mathrm{O}$. W warunkach niedoboru utlenionych przenośników elektronów (np. długotrwałe silne natężenie światła) elektrony z PSI mogą zostać przeniesione bezpośrednio na $\mathrm{O}_{2}$, prowadząc do powstania anionorodnika ponadtlenkowego $\left(\mathrm{O}_{2}{ }^{\circ}\right)$. Kolejne reakcje cyklu mają za zadanie utylizację $\mathrm{O}_{2}$; dysmutaza ponadtlenkowa katalizuje przemianę $\mathrm{O}_{2}$ " do $\mathrm{O}_{2} \mathrm{i} \mathrm{H}_{2} \mathrm{O}_{2}$. Następnie $\mathrm{w}$ cyklu glutationowo-askorbinianowym peroksydaza L-askorbinianowa redukuje $\mathrm{H}_{2} \mathrm{O}_{2}$ do $\mathrm{H}_{2} \mathrm{O}$. Produktem utlenienia askorbinianu jest monodehydroaskorbinian, który jest ponownie przekształcany do askorbinianu w wyniku aktywności reduktazy monodehydroaskorbinianowej lub reduktazy dehydroaskorbinianowej wykorzystującej do tego procesu pulę glutationu, odnawianą dzięki aktywności reduktazy glutationowej [40].

\section{INNE ELEMENTY ŁAŃCUCHA} TRANSPORTU ELEKTRONÓW

Redukcja PQ jest również możliwa dzięki aktywności desaturazy fitoenu zaangażowanej w syntezę karotenoidów. Bezpośrednim akceptorem elektronu reakcji przekształce- nia fitoenu jest tylakoidowa pula PQ, wymagana do aktywności desaturazy fitoenu [33].

Pośrednio w system transportu elektronów są zaangażowane błonowe białka transportowe zlokalizowane $\mathrm{w}$ błonach tylakoidów. Jednym z nich jest KEA3 (ang. thylakoid $\mathrm{K}^{+}$efflux antiporter 3) - antyport $\mathrm{K}^{+} / \mathrm{H}^{+}$. KEA3 transportuje $\mathrm{H}^{+} \mathrm{z}$ lumen tylakoidów do stromy obniżając $\Delta \mathrm{pH}$. Z kolei import $\mathrm{K}^{+}$do lumen tylakoidów utrzymuje prawidłowy potencjał błonowy [41]. Jest to dodatkowy element regulatorowy umożliwiający zmniejszenie gradientu $\mathrm{pH}$ w przypadku niewystarczającej aktywności syntazy ATP.

\section{PRZEMIANY SZCZAWIOOCTAN-JABŁCZAN}

Aktywność chloroplastowej dehydrogenazy jabłczanowej zależnej od NADPH (MDH) umożliwia przekazywanie siły redukcyjnej między przedziałami komórki, utrzymując równowagę redoks całego systemu. $\mathrm{W}$ chloroplastach aktywność MDH jest ściśle regulowana przez światło. MDH ulega aktywacji tylko w środowisku redukującym, w czasie wzrostu stosunku NADPH/NADP ${ }^{+}$. Wykorzystuje wtedy NADPH jako substrat redukcji szczawiooctanu do jabłcza$\mathrm{nu}$, odnawiając pulę akceptora elektronów - NADP ${ }^{+}$. Powstały jabłczan jest transportowany poza chloroplasty np. do mitochondriów, gdzie jest ponownie przekształcany do szczawiooctanu z wytworzeniem NADH. Cykl przemian szczawiooctan-jabłczan jest jednym z mechanizmów unikania generacji reaktywnych form tlenu [38].

\section{MECHANIZMY REGULUJACE WYDAJNOŚĆ REAKCJI ŚWIETLNYCH FOTOSYNTEZY}

Optymalizacja procesu fotosyntezy w zmiennych warunkach świetlnych wymaga równowagi między (i) absorpcją energii świetlnej, (ii) konwersją energii słonecznej w energię chemiczną oraz (iii) stanem redoks chloroplastu. Wymaga to istnienia szeregu mechanizmów regulacyjnych działających na różnych poziomach organizacji. Ograniczając rozważania jedynie do błon tylakoidów można powiedzieć, że obserwowane procesy adaptacyjne powinny prowadzić do osiągnięcia takiego stanu fizyko-chemicznego błon biologicznych, który zapewnia optymalną, $\mathrm{w}$ danych warunkach środowiska, wydajność procesów fotochemicznych. Z kolei spadek aktywności fotochemicznej będzie wskazywał na brak lub niedostatek mechanizmów przeciwdziałających niekorzystnemu stanowi fizyko-chemicznemu błon tylakoidów.

Można wyróżnić dwa typy regulacji: długoterminową i krótkoterminową. Pierwsza obejmuje głównie zmiany w ekspresji genów, kodujących białka tylakoidów i enzymy biorące udział w syntezie barwników i lipidów polarnych w odpowiedzi na długotrwałą stymulację [42]. Skala czasowa tych procesów to dni, a nawet tygodnie, w zależności od gatunku rośliny i intensywności bodźca. Natomiast efekty działania mechanizmów krótkoterminowych są widoczne już po kilku minutach od zaistniałej zmiany i polegają zazwyczaj na odwracalnych modyfikacjach potranslacyjnych białek (głównie fosforylacji) oraz przemianach karotenoidów. Można do nich zaliczyć niefotochemiczne wygaszanie energii wzbudzenia (NPQ), proces przejścia stanów, 


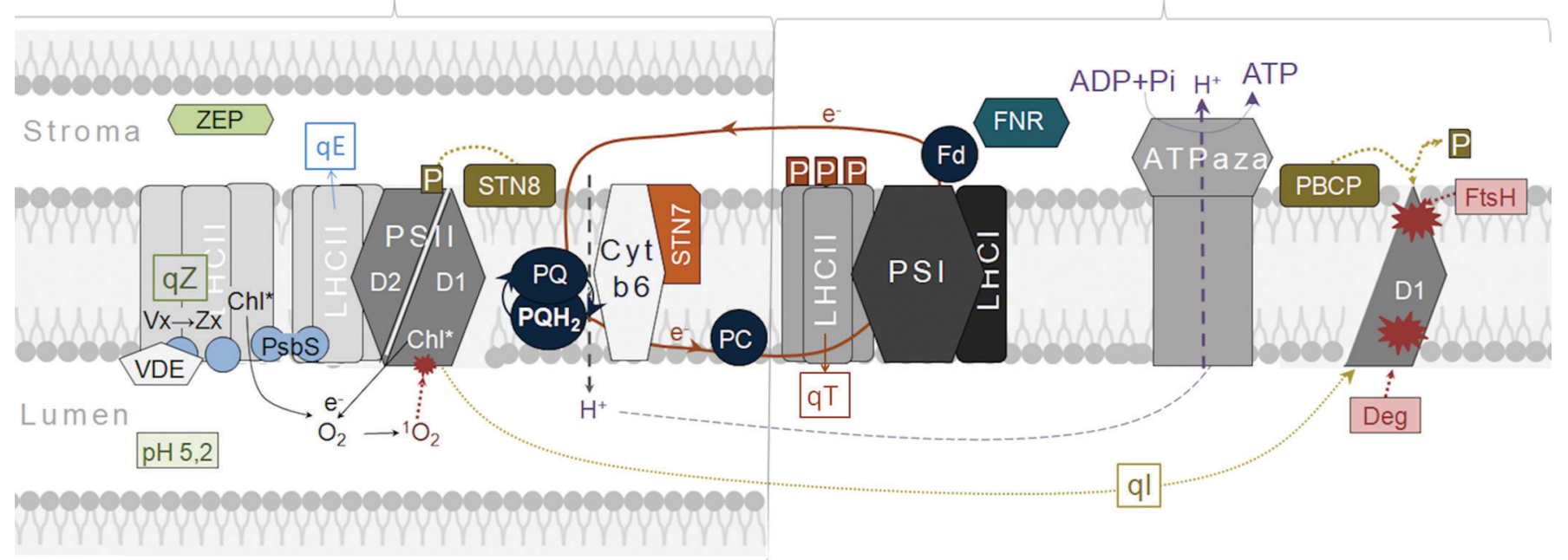

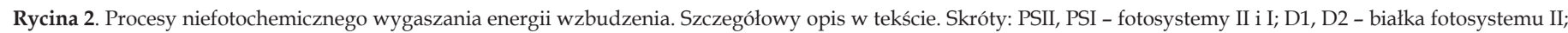

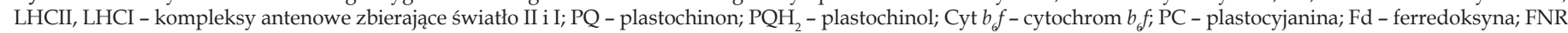

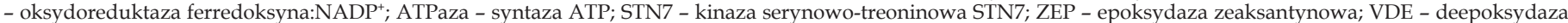

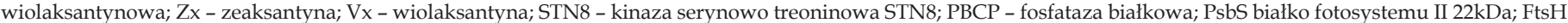

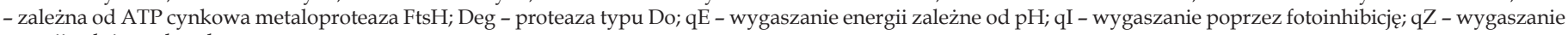
energii zależne od zeaksantyny.

cykl naprawczy białka D1 oraz alternatywne szlaki transportu elektronów [26].

\section{NIEFOTOCHEMICZNE WYGASZANIE ENERGII WZBUDZENIA}

Ekspozycja aparatu fotosyntetycznego na zbyt wysokie natężenie światła prowadzi do zaburzenia równowagi między ilością absorbowanej przez kompleksy antenowe energii świetlnej a możliwością jej przekształcenia w NADPH i ATP. Utrzymywanie się takiego stanu nierównowagi prowadzi ostatecznie do uszkodzenia kompleksów fotosyntetycznych i spadku wydajności fotosyntezy. Jednym z najszybszych i najwydajniejszych mechanizmów chroniących aparat fotosyntetyczny przed foto-uszkodzeniami jest NPQ, które umożliwia rozproszenie nadmiaru energii wzbudzenia elektronowego $\mathrm{m}$. in. na sposób cieplny $[9,43]$. NPQ jest procesem złożonym, opartym o wiele mechanizmów molekularnych, które ciągle są przedmiotem debaty naukowej [44] (Ryc. 2). Bazując na badaniach nad kinetyką NPQ w warunkach in vivo i in vitro wyodrębniono:

- trzy główne regulatory: (i) gradient protonów $(\Delta \mathrm{pH}) \mathrm{w}$ poprzek błony tylakoidów; (ii) zeaksantyna (Zx); (iii) białko PsbS (ang. Photosystem II 22 kDa protein)

- cztery główne komponenty, każdy działający w oparciu o inne mechanizmy molekularne: (i) qE - wygaszanie zależnie od $\Delta \mathrm{pH}$; (ii) qT - wygaszanie związane z procesem przejścia stananów; (iii) qZ - wygaszanie zależne od zeaksantyny; (iv) qI - wygaszanie poprzez fotoinhibicję.

Komponent qE

W przeciągu kilku minut od pojawienia się bodźca świetlnego zostaje aktywowane wygaszanie wysokoenergetyczne $\mathrm{qE}$, zależne od $\Delta \mathrm{pH}[32,37,38]$, do którego aktywacji jest niezbędne homodimeryczne białko PsbS, przyłączone do superkompleksu PSII-LHCII [37,38]. Spadek pH lumen do $\sim 5$ powoduje aktywację białek PsbS - następuje ich protonacja i monomeryzacja, co zwiększa ich powinowactwo do trimerów LHCII. Wzrost nieuporządkowania kompleksów PSII-LHCII sprzyja tworzeniu centrów wygaszających, w których następuje relaksacja stanów wzbudzonych chlorofilu $[9,47,48]$. Dodatkowo obecność Zx wpływa na wydajność działania białka PsbS, a tym samym na wydajność qE $[46,49]$.

\section{Komponent qZ}

Utrzymujące się silne natężenie światła aktywuje mechanizm wygaszania energii zależny od Zx (qZ) [46,49], który jest związany z cyklem ksantofilowym, czyli wzajemnymi przemianami wiolaksantyna $(\mathrm{Vx}) \leftrightarrow$ zeaksantyna $(\mathrm{Zx})$ $[43,44]$. Spadek pH lumen indukuje zmianę konformacji deepoksydazy wiolaksantynowej (VDE), co promuje wiązanie enzymu do błon tylakoidów po stronie lumen, gdzie znajduje się substrat reakcji [33]. Reakcja deepoksydacji przebiega dwustopniowo; redukcja jednej grupy epoksydowej Vx prowadzi do powstania anteraksantyny, która w kolejnej reakcji deepoksydacji jest przekształcana do Zx [11]. W optymalnym $\mathrm{pH} \sim 6$ i niezależnie od obecności światła przebiega reakcja odwrotna do syntezy Zx - epoksydacja. Przeprowadza ją epoksydaza zeaksantynowa zlokalizowana w stromie chloroplastu [48].

Nagromadzenie Zx indukuje wiązanie PsbS do monomerycznych anten PSII: Lhcb6 i Lhcb5 [9]. Następuje reorganizacja zewnętrznych anten PSII - odłączenie LHCII od PSII, agregacja trimerów LHCII i zmniejszenie rozmiaru anten PSII $[8,33,44]$. Zagregowane trimery LHCII rozpraszają zabsorbowaną energię świetlną na drodze emisji cieplnej $[47,55]$. O ile relaksacja qE jest procesem szybkim, to wygaszenie komponentu qZ może trwać nawet godzinę. Jest 
to związane z szybkością wymiany Zx na Vx w LHCII oraz samą szybkością procesu epoksydacji Zx [49,57].

Komponent qI

Długotrwała ekspozycja na silne natężenie światła indukuje komponent qI związany z fotoinhibicją PSII, czyli trwałymi uszkodzeniami PSII, głównie białka D1. Relaksacja qI wymaga wymiany uszkodzonych podjednostek na nowo zsyntetyzowane, która odbywa poprzez cykl naprawczy PSII $[49,57]$. Zaproponowano występowanie komponentu NPQ ściśle związanego z pojawieniem się stresu abiotycznego takiego, jak utrzymujące się wysokie natężenie światła (HL) - qH, będącym wolno relaksującym elementem qI, zależnym od plastydowej lipokaliny LCNP (ang. plastid lipocalin). U roślin uprawianych w warunkach niskiego natężenia światła (LL) element $\mathrm{qH}$ nie występuje, natomiast sama LCNP jest zaangażowana w ochronę lipidów przed peroksydacją i wykazuje podwyższoną ekspresję w warunkach. W procesie qH LCNP ma modyfikować cząsteczki w obrębie lub sąsiedztwie anten fotosyntetycznych zmieniając ich konformację ze stanu zbierającego energię świetlną na stan wygaszający $[63,68,69]$.

\section{CYKL NAPRAWCZY FOTOSYSTEMU II}

Cykl życia białka centrum reakcji PSII - D1 jest krótki (około 30 minut) i ulega skróceniu w warunkach stresu świetlnego [8,45]. W wyniku uszkodzenia białka D1 następuje fosforylacja białek rdzeniowych PSII, którą przeprowadza kinaza serynowo-treoninowa STN8 [59]. Fosforylacja chroni białka rdzeniowe PSII przed proteolizą oraz zwiększa płynność błony, co ułatwia transport uszkodzonych jednostek PSII [33,49]. Fosforylowany PSII migruje do tylakoidów stromy, gdzie ulega monomeryzacji. Transport PSII poza tylakoidy gran umożliwia proteazom dostęp do uszkodzonego białka [61]. W lamellach stromy następuje defosforylacja D1 (katalizowana przez fosfataze PBCP), co zwiększa wydajność degradacji D1 przez proteazy FtsH (ang. ATP-dependent zinc metalloprotease FtsH) i Deg (ang. Protease Do-like) [62]. W miejsce uszkodzonego D1 w PSII dołączane jest nowo zsyntetyzowane D1 [61-63]. Następnie zachodzi odbudowa monomeru PSII i jego dimeryzacja, które mają miejsce w trakcie ponownej migracji kompleksu do tylakoidów gran. Mechanizmowi naprawczemu podlegają również białka D2, CP43 i PsbH [61].

W cyklu naprawczym PSII bierze udział wiele białek pomocniczych m. in. tylakoidowe białka MPH1 (ang. Maintenance of PSII Under High Light 1) i HHL1 (ang. Hypersensitive to High Light 1), który wchodząc w interakcje z LQY1 (ang. Low Quantum Yield of Photosystem II 1) reguluje mechanizmy naprawcze uszkodzonego kompleksu PSII. W cykl naprawczy PSII są również zaangażowane białka OHP1 (ang. One-Helix Protein 1), OHP2 (ang. One-Helix Protein 1) i HCF244 (ang. High Chlorophyll Fluorescence 244) formujące heterotrimer [62]. Po monomeryzacji PSII białko HHL1 wchodzi w interakcje z CP43 po czym następuje ich uwolnienie z PSII i skierowanie CP43 na ścieżkę degradacji lub naprawy. Białko HHL1 może również brać udział w ponownym formowaniu PSII. Wchodzi w interakcje z CP43 i CP47 w celu ułatwienia tworzenia miejsca ich wiązania $\mathrm{w}$ PSII. Prawdopodobnie temu proceso- wi towarzyszy białko LQY1 wchodzace w interakcje z HHL1 [59]. W trakcie syntezy PSII de novo lub procesu naprawczego formuje się minimalny kompleks centrum reakcji, złożony między innymi z D1, D2 i PsbE, który jest stabilizowany przez białka OHP1/OHP2 oraz białka z rodziny HCF. Białka $\mathrm{OHP1/OHP2} \mathrm{są} \mathrm{przenośnikami} \mathrm{chlorofilu} a$ oraz $\beta$-karotenu i umożliwiają wbudowanie ich do białek D1/D2 poprzez bezpośrednią interakcję. Następnie zachodzi przyłączenie CP43, CP47 i mniejszych podjednostek kompleksu PSII. Gdy PSII osiąga stabilną konformacje, OHP1/OHP2 oraz pozostałe białka stabilizujące ulegają odłączeniu [64,65].

\section{PROCES PRZEJŚCIA STANÓW}

Odwracalna fosforylacja jest powszechną modyfikacją białek zaangażowaną $\mathrm{w}$ regulację metabolizmu, ścieżki transdukcji sygnału i ekspresję genów [60, 66]. W odpowiedzi na stan redoks chloroplastu fosforylacji podlega co najmniej 13 białek zlokalizowanych w tylakoidach. Większość z nich należy do PSII: D1, D2, CP43, PsbH i LHCII: Lhcb1, Lhcb2, Lhcb4 [11,60,67]. Fosforylacja pełni rolę fotoprotekcyjną. Zapobiega uszkodzeniu PSII, bierze udział w regulacji rozmiaru anten przy długoterminowym przystosowaniu do warunków świetlnych oraz dystrybucji energii wzbudzenia między PSII i PSI $[45,60]$.

W klasycznym ujęciu w czasie krótkoterminowej aklimatyzacji do zmiennych warunków świetlnych następuje fosforylacja białek Lhcb i migracja LHCII z PSII do PSI $[34,53,55]$, co jest określane jako proces przejścia stanów (przejście ze stanu pierwszego do drugiego), w celu osiągnięcia równowagi stanu redoks puli PQ (Ryc. 3) [45,68].

W stanie pierwszym, gdy PSI ulega preferencyjnemu wzbudzeniu, anteny LHCII są związane z PSII, a pula PQ jest w większości utleniona (Ryc. 3A). Kiedy dochodzi do preferencyjnego wzbudzenia PSII, wzrasta poziom redukcji puli PQ. Gdy $\mathrm{PQH}_{2}$ wiąże się z kompleksem Cyt $\mathrm{b}_{6} f$, dochodzi do aktywacji kinazy serynowo-treoninowej (STN7), która jest zaangażowana w fosforylację białek kompleksu LHCII: Lhcb1 i Lhcb2 [16,33,53,57]. W wyniku fosforylacji LHCII traci powinowactwo do PSII i migruje do nieścieśnionych tylakoidów, gdzie zaczyna oddziaływać z PSI (stan drugi) (Ryc. 3B) [32,70]. Powstaje wówczas superkompleks PSI-LHCI-LHCII, w którym centrum reakcji P700 może odbierać elektrony zarówno od anten LHCI, jak i LHCII. Warunkiem transferu energii z LHCII do PSI jest silna fosforylacja białka Lhcb2 [11].

Proces fosforylacji LHCII jest odwracalny. Spadek wzbudzenia PSII powoduje zmniejszenie stężenia $\mathrm{PQH}_{2}$ i w efekcie obniżenie aktywności STN7. Prowadzi to do wzrostu wydajności konstytutywnej fosfatazy białkowej TAP38/ PPH1 (ang. Thylakoid Aassociated Phosphatase 38/Protein Phosphatase 1), która pełni główną rolę w defosforylacji LHCII $[11,66]$. Defosforylowany LHCII traci powinowactwo do PSI i migruje ponownie do tylakoidów gran, gdzie może utworzyć kompleks PSII-LHCII [66].

Proces przejścia stanów jest uznawany za jeden z komponentów NPQ - qT, jednak u roślin wyższych nie ma dużego znaczenia ze względu na utrudnioną migrację białek $\mathrm{w}$ silnie ścieśnionych tylakoidach gran, za wyjątkiem warunków sła- 


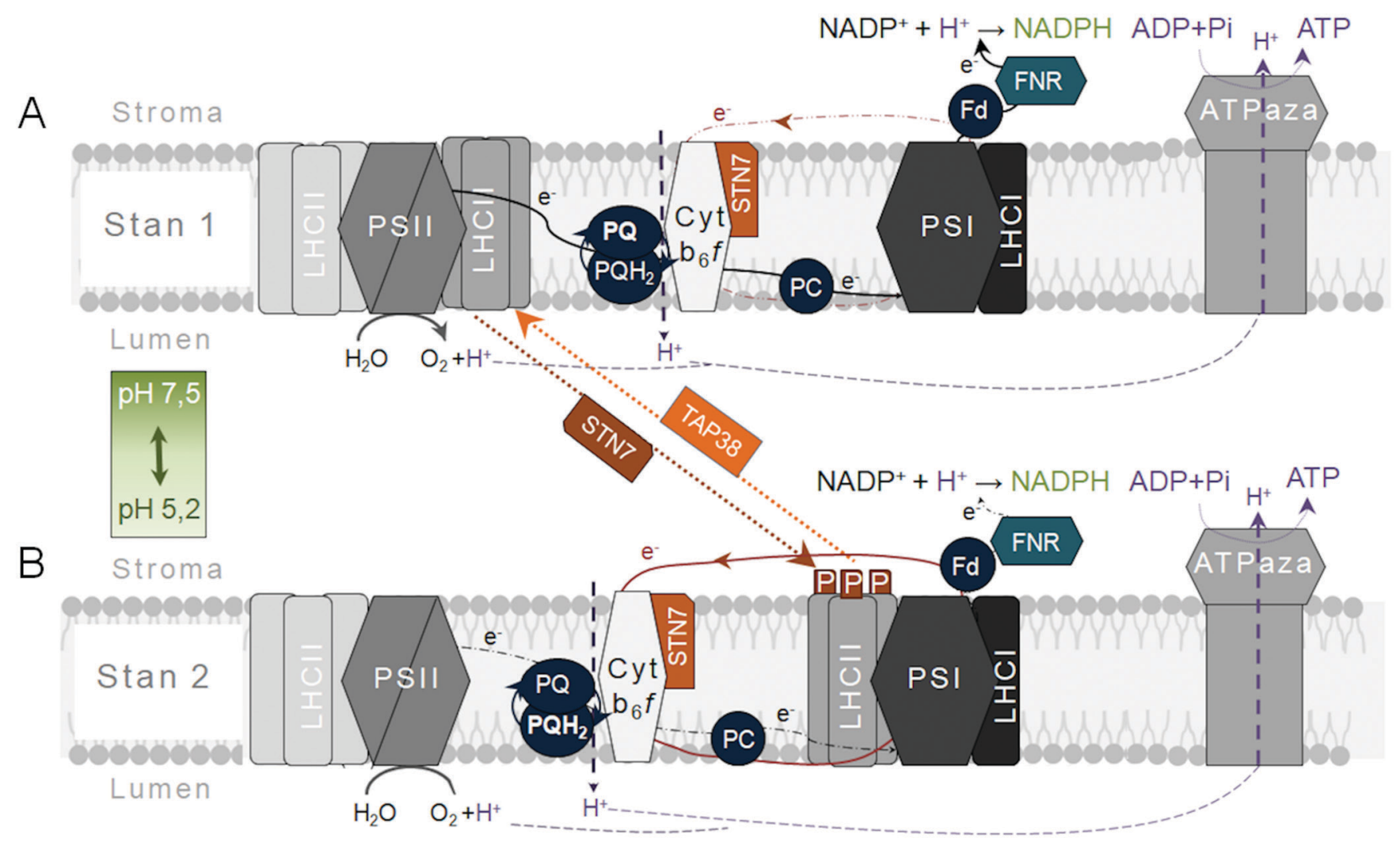

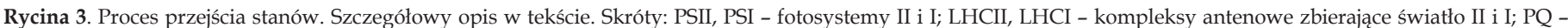

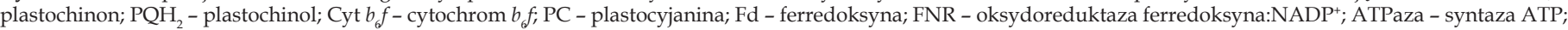
STN7 - kinaza serynowo-treoninowa STN7; TAP38 - fosfataza białkowa 2C 57.

bego natężenia światła. Według najnowszych badań proces migracji fosforylowanego LHCII nie występuje z dużą wydajnością. Postuluje się istnienie dwóch niezależnych puli LHCII mogących ulegać fosforylacji. Pierwsza z nich - zlokalizowana w tylakoidach gran, po fosforylacji odłącza się od PSII i pozostaje w granach. Druga pula - zlokalizowana w tylakoidach stromy i obszarach marginalnych gran, po fosforylacji przyłącza się do PSI [71]. Innym postulowanym mechanizmem jest tworzenie kompleksu PSII-LHCII-PSI-LHCI w obszarach marginalnych gran, w którym LHCII jest nadal połączone z PSII ale przekazuje energię wzbudzenia głównie do PSI [72].

Proces przejścia stanów, chociaż istotny w warunkach LL, nie występuje $w$ warunkach HL. Wynika to $z$ dezaktywacji kinazy STN7 i utrzymującej się aktywności antagonistycznej fosfatazy PPH1/TAP38, przez co nie zostaje podtrzymany stan fosforylacji LHCII. Proces dezaktywacji STN7 nie jest jasny. Może wynikać ze zmian konformacyjnych wywołanych stanem redoks łańcucha transportu elektronów lub potencjału błony, albo następować przez oddziaływanie mostków dwusiarczkowych STN7 z tioredoksyną [73]. W czasie stałego HL defosforylacja LHCII hamuje dalszy transfer energii do PSI [42].

\section{PODSUMOWANIE}

Rośliny są wystawione na zmienność warunków środowiska, do których muszą się płynnie dostosowywać. Przede wszystkim do intensywności oświetlenia, które zmienia się w cyklu dobowym i rocznym. W drodze ewolucji rośliny wykształciły liczne mechanizmy umożliwiające przetrwanie w warunkach zarówno słabego, jak i silnego natężenia światła. Polegają one na jego unikaniu i neutralizacji szkodliwych skutków, a ostatecznie, przy długotrwałych niekorzystnych warunkach, na aklimatyzacji. Większość tych mechanizmów dotyczy procesu fotosyntezy, który podlega ścisłej kontroli na wszystkich poziomach organizacji. Należy podkreślić, że współwystępującym efektem aktywności procesów regulacyjnych są zmiany w strukturze błon tylakoidów, będące z jednej strony następstwem modyfikacji białek i przemian lipidów, a z drugiej warunkiem umożliwiającym zajście kolejnych etapów procesu. Utrzymanie maksymalnej, $\mathrm{w}$ danych warunkach, wydajności fotosyntezy jest wypadkową krótko- i długoterminowych procesów regulacyjnych, prowadzących do precyzyjnej reorganizacji składu lipidowego, kompleksów fotosyntetycznych i zmian w strukturze systemu błon tylakoidów.

\section{PIŚMIENNICTWO}

1. Johnson MP (2016) Photosynthesis. Essays Biochem 60: 255-273

2. Tikhonov AN (2018) The Cytochrome b 6 f Complex: Biophysical Aspects of Its Functioning in Chloroplasts. Subcell Biochem 87: 287328

3. Rochaix J (2011) Regulation of photosynthetic electron transport. BBA - Bioenerg 1807: 375-383

4. Wei X, Su X, Cao P, Liu X, Chang W, Li M, Zhang X, Liu Z (2016) Structure of spinach photosystem II-LHCII supercomplex at $3.2 \AA$ resolution. Nature 534: 69-74 
5. Caffarri S, Tibiletti T, Jennings R, Santabarbara S (2014) A Comparison Between Plant Photosystem I and Photosystem II Architecture and Functioning. Curr Protein Pept Sci 15: 296-331

6. Boekema EJ, Van Breemen JFL, Van Roon H, Dekker JP (2000) Arrangement of photosystem II supercomplexes in crystalline macrodomains within the thylakoid membrane of green plant chloroplasts. J Mol Biol 301: 1123-1133

7. Timperio AM, Gevi F, Ceci LR, Zolla L (2012) Acclimation to intense light implies changes at the level of trimeric subunits involved in the structural organization of the main light-harvesting complex of photosystem II (LHCII) and their isoforms. Plant Physiol Biochem 50: 8-14

8. Luciński R, Jackowski G (2013) AtFtsH heterocomplex-mediated degradation of apoproteins of the major light harvesting complex of photosystem II (LHCII) in response to stresses. J Plant Physiol 170: 1082-1089

9. Sacharz J, Giovagnetti V, Ungerer P, Mastroianni G, Ruban AV (2017) The xanthophyll cycle affects reversible interactions between PsbS and light-harvesting complex II to control non-photochemical quenching. Nat Plants 3: 16225

10. Caffarri S, Kouřil R, Kereïche S, Boekema EJ, Croce R (2009) Functional architecture of higher plant photosystem II supercomplexes. EMBO J 28: 3052-3063

11. Rantala M, Tikkanen M, Aro EM (2017) Proteomic characterization of hierarchical megacomplex formation in Arabidopsis thylakoid membrane. Plant J 92: 951-962

12. Mazor Y, Borovikova A, Caspy I, Nelson N (2017) Structure of the plant photosystem I supercomplex at $2.6 \AA$ resolution. Nat Plants 3 : $1-9$

13. Ihalainen JA, Jensen PE, Haldrup A, Van Stokkum IHM, Van Grondelle R, Scheller HV, Dekker JP (2002) Pigment organization and energy transfer dynamics in isolated photosystem I (PSI) complexes from Arabidopsis thaliana depleted of the PSI-G, PSI-K, PSI-L, or PSI-N subunit. Biophys J 83: 2190-2201

14. Pan X, Ma J, Su X, Cao P, Chang W, Liu Z, Zhang X, Li M (2018) Structure of the maize photosystem I supercomplex with light-harvesting complexes I and II. Science 360: 1109-1113

15. Nellaepalli S, Ozawa S, Kuroda H, Takahashi Y (2018) The photosystem I assembly apparatus consisting of Ycf3-Y3IP1 and Ycf4 modules. Nat Commun 2439: 1-10

16. Busch A, Hippler M (2011) The structure and function of eukaryotic photosystem I. Biochim Biophys Acta - Bioenerg 1807: 864-77

17. Shikanai T (2016) Chloroplast NDH: A different enzyme with a structure similar to that of respiratory NADH dehydrogenase. Biochim Biophys Acta - Bioenerg 1857: 1015-1022

18. Qin X, Wang W, Wang K, Xin Y, Kuang T (2011) Isolation and characteristics of the PSI-LHCI-LHCII supercomplex under high light. Photochem Photobiol 87: 143-150

19. Luján MA, Lorente P, Zazubovich V, Picorel R (2017) A simple and efficient method to prepare pure dimers and monomers of the cytochrome b 6 f complex from spinach. Photosynth Res 132: 305-309

20. Dibrova D V, Shalaeva DN, Galperin MY, Mulkidjanian AY (2017) Emergence of cytochrome bc complexes in the context of photosynthesis. Physiol Plant 161: 150-170

21. Cramer WA, Zhang H, Yan J, Kurisu G, Smith JL (2004) Evolution of Photosynthesis: Time-Independent Structure of the Cytochrome $\mathrm{b} 6 \mathrm{f}$. Biochemistry 43: 5921-5929

22. Junge W, Lill H, Engelbrecht S (1997) ATP synthase: An electrochemical transducer with rotatory mechanics. Trends Biochem Sci 22: $420-423$

23. Oster G, Wang H (1999) ATP synthase: Two motors, two fuels. Structure 7: 67-72

24. Hahn A, Vonck J, Mills DJ, Meier T, Kühlbrandt W (2018) Structure, mechanism, and regulation of the chloroplast ATP synthase. Science 360: eaat 4318

25. Weber J, Senior AE (2000) ATP synthase: what we know about ATP hydrolysis and what we do not know about ATP synthesis. Biochim Biophys Acta 1458: 300-309
26. Nikkanen L, Toivola J, Trotta A, Diaz MG, Tikkanen M, Aro EM, Rintamäki E (2018) Regulation of cyclic electron flow by chloroplast NADPH-dependent thioredoxin system. Plant Direct 2: e00093

27. Garstka M (2007) Strukturalne Podstawy Reakcji Świetlnych Fotosyntezy. Postępy Biol Komórki 34: 445-476

28. Tikhonov A, Vershubskii A (2014) Computer modeling of electron and proton transport in chloroplasts. BioSystems 121: 1-21

29. Nugent JHA (1996) Oxygenic photosynthesis Electron transfer in photosystem I and photosystem II. Eur J Biochem 237: 519-531

30. Ishikita H, Knapp EW (2005) Control of quinone redox potentials in Photosystem II: Electron transfer and photoprotection. J Am Chem Soc 127: $14714-14720$

31. Brettel K, Leibl W (2001) Electron transfer in photosystem I. Biochim Biophys Acta - Bioenerg 1507: 100-114

32. Yamori W, Shikanai T (2016) Physiological Functions of Cyclic Electron Transport Around Photosystem I in Sustaining Photosynthesis and Plant Growth. Annu Rev Plant Biol 67: 81-106

33. Wang D, Fu A (2016) The Plastid Terminal Oxidase is a Key Factor Balancing the Redox State of Thylakoid Membrane. Enzymes 40: 143-171

34. Strzałka K (2015) Przemiany związków organicznych i energii u roślin. W: Zienkiewicz I (red) Fizjologia Roślin, Wydawnictwo Naukowe PWN SA, Warszawa, str. 285-295

35. Smirnov AY, Nori F (2012) Modeling the Q-cycle mechanism of transmembrane energy conversion. Phys Biol 9: 016011

36. Suorsa M, Rossi F, Tadini L, Labs M, Colombo M, Jahns P, Kater MMM, Leister D, Finazzi G, Aro EM, Barbato R, Pesaresi P (2016) PGR5-PGRL1-Dependent Cyclic Electron Transport Modulates Linear Electron Transport Rate in Arabidopsis thaliana. Mol Plant 9: 271-288

37. Rumeau D, Peltier G, Cournac L (2007) Chlororespiration and cyclic electron flow around PSI during photosynthesis and plant stress response. Plant, Cell Environ 30: 1041-1051

38. Selinski J, Scheibe R (2019) Malate valves: old shuttles with new perspectives. Plant Biol 21: 21-30

39. Tullberg A, Alexciev K, Pfannschmidt T, Allen JF (2000) Photosynthetic electron flow regulates transcription of the $\mathrm{psaB}$ gene in pea (Pisum sativum L.) chloroplasts through the redox state of the plastoquinone pool. Plant Cell Physiol 41: 1045-1054

40. Szymańska R, Ślesak I, Orzechowska A, Kruk J (2017) Physiological and biochemical responses to high light and temperature stress in plants. Environ Exp Bot 139: 165-177

41. Alric J, Johnson X (2017) Alternative electron transport pathways in photosynthesis: a confluence of regulation. Curr Opin Plant Biol 37: $78-86$

42. Gururani MA, Venkatesh J, Tran LP (2015) Regulation of Photosynthesis during Abiotic Stress-Induced Photoinhibition. Mol Plant 8: 1304-1320

43. Xu P, Tian L, Kloz M, Croce R (2015) Molecular insights into Zeaxanthin-dependent quenching in higher plants. Sci Rep 5: 1-10

44. Ruban A V (2016) Nonphotochemical Chlorophyll Fluorescence Quenching: Mechanism and Effectiveness in Protecting Plants from Photodamage. Plant Physiol 170: 1903-1916

45. Li Z, Wakao S, Fischer BB, Niyogi KK (2009) Sensing and Responding to Excess Light. Annu Rev Plant Biol 60: 239-260

46. Gerotto C, Franchin C, Arrigoni G, Morosinotto T (2015) In Vivo Identification of Photosystem II Light Harvesting Complexes Interacting with PHOTOSYSTEM II SUBUNIT S. Plant Physiol 168: 1747-1761

47. Correa-Galvis V, Poschmann G, Melzer M, Stühler K, Jahns P (2016) PsbS interactions involved in the activation of energy dissipation in Arabidopsis. Nat Plants 167: 176-183

48. Han H, Gao S, Li B, Dong XC, Feng HL, Meng QW (2010) Overexpression of violaxanthin de-epoxidase gene alleviates photoinhibition of PSII and PSI in tomato during high light and chilling stress. J Plant Physiol 15: 176-183

49. Ilioaia C, Duffy CDP, Johnson MP, Ruban A V. (2013) Changes in the Energy Transfer Pathways within Photosystem II Antenna Induced by Xanthophyll Cycle Activity. J Phys Chem B 117: 5841-5847 
50.Strzałka K, Kostecka-Gugała A, Latowski D (2003) Carotenoids and Environmental Stress in Plants: Significance of Carotenoid-Mediated Modulation of Membrane Physical Properties. Russ J Plant Physiol 50: 168-173

51. Yamamoto HY (1979) Biochemistry of the violaxanthin cycle in higher plants. Pure Appl Chem 51: 639-648

52. Pfundel EE, Dilley RA (1993) The pH Dependence of Violaxanthin Deepoxidation in Isolated Pea Chloroplasts. Plant Physiol 101: 65-71

53. Johnson MP, Goral TK, Duffy CDP, Brain APR, Mullineaux CW, Ruban A V. (2011) Photoprotective Energy Dissipation Involves the Reorganization of Photosystem II Light-Harvesting Complexes in the Grana Membranes of Spinach Chloroplasts. Plant Cell 23: 1468-1479

54. Kereïche S, Kiss AZ, Kouřil R, Boekema EJ, Horton P (2010) The PsbS protein controls the macro-organisation of photosystem II complexes in the grana membranes of higher plant chloroplasts. FEBS Lett 584: 759-764.

55. Miloslavina Y, Wehner A, Lambrev PH, Wientjes E, Reus M, Garab G, Croce R, Holzwarth AR (2008) Far-red fluorescence: A direct spectroscopic marker for LHCII oligomer formation in non-photochemical quenching. FEBS Lett 582: 3625-3631

56. Kress E, Jahns P (2017) The Dynamics of Energy Dissipation and Xanthophyll Conversion in Arabidopsis Indicate an Indirect Photoprotective Role of Zeaxanthin in Slowly Inducible and Relaxing Components of Non-photochemical Quenching of Excitation Energy. Front Plant Sci 8: 1-17

57. Tietz S, Hall CC, Cruz JA, Kramer DM (2017) NPQ(T): a chlorophyll fluorescence parameter for rapid estimation and imaging of non-photochemical quenching of excitons in photosystem-II-associated antenna complexes. Plant Cell Environ 40: 1243-1255

58. Liu J (2019) A New Light on Photosystem II Maintenance in Oxygenic Photosynthesis. Front Plant Sci 10: 975

59. Tikkanen M, Aro E (2012) Biochimica et Biophysica Acta Thylakoid protein phosphorylation in dynamic regulation of photosystem II in higher plants. BBA - Bioenerg 1817: 232-238

60. Ebbert V, Demmig-Adams B, Adams WW, Mueh KE, Staehelin LA (2001) Correlation between persistent forms of zeaxanthin-dependent energy dissipation and thylakoid protein phosphorylation. Photosynth Res 67: 63-78

61. Theis J, Schroda M (2016) Revisiting the photosystem II repair cycle. Plant Signal Behav 11: e1218587

62. Knopf RR, Adam Z (2018) Lumenal exposed regions of the D1 protein of PSII are long enough to be degraded by the chloroplast Deg1 protease. Sci Rep 8: 5230
63. Galetskiy D, Lohscheider JN (2011) Phosphorylation and nitration levels of photosynthetic proteins are conversely regulated by light stress. Plant Mol Biol 77: 461-473

64. Myouga F, Takahashi K, Tanaka R, Nagata N, Kiss AZ, Funk C, Nomura Y, Nakagami H, Jansson S, Shinozaki K (2020) Stable accumulation of photosystem II requires ONE-HELIX PROTEIN1 (OHP1) of the light harvesting-like family. Plant Physiol 176: 2277-2291

65. Li Y, Liu B, Zhang J, Kong F, Zhang L, Meng H, Li W, Rochaix JD, Li D, Peng L (2019) OHP1, OHP2, and HCF244 form a transient functional complex with the photosystem II reaction center. Plant Physiol 179: 195-208

66. Shapiguzov A, Ingelsson B, Samol I, Andres C, Kessler F, Rochaix J-D, Vener AV, Goldschmidt-Clermont M (2010) The PPH1 phosphatase is specifically involved in LHCII dephosphorylation and state transitions in Arabidopsis. Proc Natl Acad Sci 107: 4782-4787

67. Vener AV, Harms A, Sussman MR, Vierstra RD (2001) Mass Spectrometric Resolution of Reversible Protein Phosphorylation in Photosynthetic Membranes of Arabidopsis thaliana. J Biol Chem 276: 6959-6966

68. Bressan M, Bassi R, Dall'Osto L (2018) Loss of LHCI system affects LHCII re-distribution between thylakoid domains upon state transitions. Photosynth Res 135: 251-261

69. Vener AV, van Kan PJ, Rich PR, Ohad I, Andersson B (1997) Plastoquinol at the quinol oxidation site of reduced cytochrome bf mediates signal transduction between light and protein phosphorylation: thylakoid protein kinase deactivation by a single-turnover flash. Proc Natl Acad Sci U S A 94: 1585-90

70. Minagawa J (2011) State transitions-the molecular remodeling of photosynthetic supercomplexes that controls energy flow in the chloroplast. Biochim Biophys Acta - Bioenerg 1807: 897-905

71. Wood WHJ, MacGregor-Chatwin C, Barnett SFH, Mayneord GE, Huang X, Hobbs JK, Hunter CN, Johnson MP (2018) Dynamic thylakoid stacking regulates the balance between linear and cyclic photosynthetic electron transfer. Nat Plants 4: 116-127

72. Tikkanen M, Nurmi M, Suorsa M, Danielsson R, Mamedov F, Styring S, Aro EM (2008) Phosphorylation-dependent regulation of excitation energy distribution between the two photosystems in higher plants. Biochim Biophys Acta - Bioenerg 1777: 425-432

73. Shapiguzov A, Chai X, Fucile G, Longoni P, Zhang L, Rochaix J (2016) Activation of the Stt7 / STN7 Kinase through Dynamic Interactions with the Cytochrome b 6 f Complex 1. 171: 82-92

\title{
Regulatory mechanisms of photosynthesis light reactions in higher plants
}

\author{
Anna Wegrzyn, Radosław Mazur ${ }^{\bigotimes}$
}

Department of Metabolic Regulation, Institute of Biochemistry, Faculty of Biology, University of Warsaw

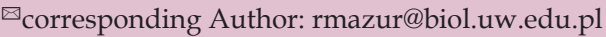

Keywords: chloroplast electron transfer chain, nonphotochemical quenching, photoinhibition, photosynthesis, state transition

\begin{abstract}
The light phase of photosynthesis is a key energy process in higher plants. Its purpose is to convert light energy into chemical one stored in ATP and NADPH molecules, which are then used to assimilate $\mathrm{CO}_{2}$ and in numerous metabolic processes. Maintaining optimal photosynthesis performance requires strict regulation of thylakoid membranes organization and rapid response to changing environmental conditions. The main factor affecting photosynthesis is light, which, if applied in excessive amounts, leads to a slowdown in the process. Therefore, plants have developed many protective mechanisms regulating the light reactions of photosynthesis and operating at the level of light energy absorption, electron transport, and the distribution and use of reducing power. These include, among others: (i) non-photochemical energy quenching regulating the amount of excitation energy delivered to the photosystems; (ii) 'state transition' process redistributing excitation energy between photosystems; (iii) redundant electron transport pathways responsible for maintaining redox balance in chloroplasts. All these mechanisms, in combination with antioxidant systems, are designed to maintain the function of the photosynthetic apparatus in adverse growth conditions.
\end{abstract}

